\title{
Peningkatan Kemampuan Pemecahan Masalah Matematis Siswa Melalui Penerapan Pembelajaran Inkuiri Berbantuan Puzzle
}

\author{
Richa Karlina Nofitasari $^{1 \bowtie}$, Ratri Rahayu² dan Jayanti Putri Purwaningrum ${ }^{3}$ \\ ${ }^{1}$ Prodi Pendidikan Guru Sekolah Dasar, Universitas Muria Kudus \\ ${ }^{2,3}$ Prodi Pendidikan Matematika, Universitas Muria Kudus
}

\begin{tabular}{|c|c|}
\hline Info Artikel & Abstract \\
\hline $\begin{array}{l}\text { Sejarah Artikel: } \\
\text { Diterima } 28 \text { April } 2020 \\
\text { Direvisi } 16 \text { Mei } 2020 \\
\text { Disetujui } 16 \text { Mei } 2020 \\
\\
\text { Keywords: Inquiry, } \\
\text { Mathematics Problem } \\
\text { Solving Abilities, Segita } \\
\text { Puzzle. }\end{array}$ & $\begin{array}{l}\text { This research aims to describe the improvement (1) mathematics problem solving abilities, (2) } \\
\text { improve student learning activity, and (3) teacher teaching skill in implementing inquiry learning } \\
\text { model assisted by segita puzzle under material perimeter and area of square, rectangle, and } \\
\text { triangle. The methods of collecting data were test, observation, interview, and documentation. The } \\
\text { data analysis of the research was quantitative and qualitative analysis. The findings showed } \\
\text { improvement of the problem solving abilities average. In cycle I, it was } 68 \text {, with percentage } 71 \% \text {, } \\
\text { categorized well. It improved into } 85 \text { in cycle II with percentage } 86 \% \text {, categorized well. Student } \\
\text { learning activity average in cycle I it was } 80 \text { with predicate sufficient. It improved into } 88 \text { with } \\
\text { predicate well in cycle II. Teacher teaching skill in cycle I was } 95 \text {, or } 74 \% \text {, categorized sufficient. In } \\
\text { cycle II, it improved into } 117.65 \text {, or } 87 \% \text {, categorized well. It is concluded that the implementation } \\
\text { of inquiry model assisted by segita puzzle could improve mathematics problem solving abilities, } \\
\text { student learning activity, and teacher teaching skill. }\end{array}$ \\
\hline
\end{tabular}

Paper type:

Research paper

\begin{abstract}
Abstrak
Tujuan penelitian ini untuk mendeskripsikan peningkatan (1) kemampuan pemecahan masalah matematis siswa (2) aktivitas belajar siswa dan (3) keterampilan mengajar guru dalam penerapan pembelajaran inkuiri berbantuan puzzle segita dengan materi keliling dan luas persegi, persegi panjang, dan segitiga. Metode pengumpulan data menggunakan teknik tes, observasi, wawancara, dan dokumentasi. Analisis data yang digunakan adalah analisis data kuantitatif dan analisis kualitatif. Hasil penelitian menunjukkan terdapat peningkatan rata-rata kemampuan pemecahan masalah. Pada siklus I diperoleh rata-rata 69 mencapai persentase $71 \%$ kualifikasi cukup baik dan meningkat pada siklus II diperoleh rata-rata 85 mencapai persentase $86 \%$ kualifikasi sangat baik. Aktivitas belajar siswa pada siklus I diperoleh rata-rata 80 dengan predikat cukup baik dan meningkat diperoleh rata-rata 88 dengan predikat baik pada siklus II. Keterampilan mengajar guru pada siklus I diperoleh jumlah rata-rata 95 mencapai persentase $74 \%$ kualifikasi cukup baik, pada siklus II meningkat diperoleh rata-rata 117,67 mencapai persentase $87 \%$ kualifikasi sangat baik. Dapat disimpulkan bahwa penerapan pembelajaran inkuiri berbantuan puzzle segita dapat meningkatkan kemampuan pemecahan masalah matematis, aktivitas belajar siswa, dan keterampilan mengajar guru.
\end{abstract}

(C) 2020 Universitas Muria Kudus

\footnotetext{
Alamat korespondensi: p-ISSN 2615-4196

Program Studi Pendidikan Matematika

e-ISSN 2615-4072

Fakultas Keguruan dan Ilmu Pendidikan Universitas Muria Kudus

Kampus UMK Gondangmanis, Bae Kudus Gd. L. 1t I PO. BOX 53 Kudus

Tlp (0291) 438229 ex.147 Fax. (0291) 437198

E-mail: ratri.rahayu@umk.ac.id
} 


\section{PENDAHULUAN}

Pendidikan memiliki peran yang sangat penting dalam kehidupan manusia. Pendidikan menciptakan sumber daya manusia yang berkualitas supaya mampu berkompetensi dan melakukan persaingan global dalam kemajuan perkembangan ilmu pengetahuan dan teknologi. Tujuan pendidikan juga tercantum dalam Undang-undang Nomor 20 Tahun 2003 tentang Sistem Pendidikan Nasional, yang menyatakan bahwa sistem pendidikan nasional bertujuan memberikan pendidikan yang bermutu serta relevansi dan efisiensi untuk meningkatkan keimanan dan ketakwaan kepada Tuhan Yang Maha dan akhlak mulia dalam mencerdaskan anak bangsa sesuai dengan tuntunan perubahan lokal, nasional, maupun global dalam perkembangan ilmu pengetahuan dan teknologi (Depdiknas, 2003).

Pemerintah melakukan upaya pencapaian tujuan pendidikan nasional dengan membenahi kurikulum pendidikan. Tahun 2006 diterapkan kurikulum pendidikan tingkat satuan pendidikan (KTSP) dan diganti menjadi kurikulum $2013 \quad$ (K-13) yang mulai dilaksanakan pada tahun 2013 hingga sekarang. Pembelajaran pada kurikulum 2013 lebih berorientasi pada aktivitas belajar siswa. Sani (2015: 45) menyatakan bahwa penerapan pembelajaran kurikulum 2013 lebih ditekankan pada siswa untuk belajar observasi, mengajukan pertanyaan-pertanyaan, mengumpulkan data, menganalisis data, dan mengkomunikasikan hasil belajar. Untuk menunjang pembelajaran, guru juga diwajibkan memiliki pengetahuan mengenai pendekatan saintifik untuk memberikan pembelajaran yang berkualitas dan berhasil mencapai tujuan pembelajaran.

Matematika merupakan salah satu muatan dalam K-13. Amir dan Risnawati (2016:8) mengemukakan bahwa pembelajaran matematika merupakan suatu proses pembelajaran dalam mengembangkan kreatifitas berpikir siswa dan meningkatkan kemampuan menciptakan pengetahuan baru sebagai upaya penguasaan materi matematika secara baik. Pembelajaran matematika merupakan pembelajaran yang sangat penting dalam perkembangan ilmu pengetahuan dan teknologi sehingga termasuk dalam kompetisi persaingan global. Dalam dunia pendidikan banyak siswa yang tidak menyukai muatan matematika.

Meskipun sudah berjalan enam tahun, penerapan K-13 masih mengalami banyak kendala. Banyak siswa SD tidak menyukai matematika, matematika dianggap sebagai pembelajaran yang sulit, yang disertai dengan guru yang dianggap angker, menyeramkan, menakutkan, tidak menyenangkan, dan membosankan. Akibat jangka panjang yang didapat dalam proses pembelajaran matematika seperti ini menyebabkan siswa takut, tidak suka belajar matematika, dan merasa tertekan ketika proses belajar berlangsung sehingga menimbulkan prestasi siswa semakin rendah Pitadjeng (2015:3).

Salah satu kurang optimalnya proses pembelajaran matematika berlangsung karena banyak siswa tidak menyukai bahkan benci dengan gurunya sendiri. Hal ini menyebabkan siswa sangat sulit untuk memahami materi dan tidak tercapainya tujuan pembelajaran matematika. Seiring dengan tujuan pembelajaran matematika tersebut. Dalam pelaksanaan pembelajaran matematika harus menjadi sarana untuk meningkatkan daya pikir, kreativitas, penalaran, dan kemampuan matematis siswa dan mengaplikasikannya dalam kehidupan sehari-hari untuk memecahkan masalah.

Pitadjeng (2015: 5) menyatakan bahwa anak akan merasa senang belajar matematika dan memahami materi apabila guru juga menciptakan pembelajaran yang menyenangkan. Dalam hal ini guru harus berupaya menerapkan strategi pembelajaran yang tepat untuk siswa. banyak hal yang harus diperhatikan oleh guru, diantaranya memahami perkembangan siswa dalam proses pembelajaran matematika, memahami cara menyampaikan materi dengan menyenangkan, dan mempunyai cara tepat menjadikan siswa senang dan tidak merasa bosan ketika belajar matematika.

Berdasarkan hasil observasi pembelajaran matematika di kelas IV SDN Geneng 2. Tidak dijumpai pembelajaran yang menyenangkan. Pelaksanaan pembelajaran matematika guru masih menunjukkan sikap serius dan suasana belajar menjadi tegang. Tidak ada strategi pembelajaran yang digunakan untuk memberikan kualitas belajar. Sebelum masuk ke materi guru tidak memberikan apersepsi, menggunakan contoh dikehidupan sekitar, dan memberikan stimulus untuk menghantarkan siswa masuk kedalam materi secara pelan-pelan. Guru hanya menerangkan materi melalui buku pegangan, melakukan tanya jawab, memberi rumus secara langsung, memberikan contoh soal, melakukan drill atau memberikan soal terus menerus, dan kurangnya penanaman konsep terhadap siswa. 
Akibat yang terjadi dalam proses pembelajaran siswa merasa tertekan, merasa bosan dan tidak nyaman ketika pembelajaran matematika berlangsung. Siswa hanya pasif mendengarkan, membaca, dan mengerjakan soal-soal. Tidak ada kesempatan siswa untuk bereksperimen, berkreativitas, dan memberikan pengalaman untuk mendapatkan sebuah konsep dari usahanya sendiri. Sehingga tidak ada materi yang sudah disampaikan terkenang dipikiran siswa dan siswa lebih mudah lupa dan selalu mengalami kesulitan dalam mengerjakan soalsoal. Hal ini yang membuat siswa untuk melakukan kecurangan menyontek ketika lupa rumus dalam kesulitan mengerjakan soal.

Berdasarkan hasil wawancara dengan guru, dalam proses pembelajaran guru hanya menggunakan metode ceramah dan tanya jawab. Guru mengaitkan dengan lingkungan sekitar apabila benda tersebut mudah dijumpainya. Guru hanya menggunakan buku pedoman guru ketika mengajar, sehingga teralu sering memberikan soal-soal rutin. Sebagian besar siswa masih kurang dalam menyelesaikan soal cerita. Siswa masih kurang dan kesulitan dalam memahami kalimat dalam soal cerita dan rumus. Inilah kesulitan yang sering ditemui dalam pembelajaran matematika.

Hasil wawancara dengan beberapa siswa menunjukkan bahwa banyak ditemui siswa yang tidak menyukai pembelajaran matematika. Alasan dari mereka adalah banyak rumus yang harus dihafalkan. Guru tidak memberikan konsep untuk menentukan sebuah rumus terlebih dahulu, tetapi siswa dipaksa untuk masuk langsung ke rumus. Guru juga tidak menggunakan media pembelajaran, yang digunakan hanyalah garis busur. Siswa dibiasakan mengerjakan soal essay daripada soal cerita. Dan siswa hanya memahami mengerjakan soal cerita dengan langsung menghitung dan ada jadi, sedangkan soal biasa hanya langsung menghitung. Akibatnya siswa merasakan kesulitan bila mengerjakan soal cerita karena pertanyaan-pertanyaan yang sulit dan kesulitan dalam memahami kalimat dalam soal cerita. Hal ini sesuai dengan pernyataan guru dalam wawancara sebelumnya.

Bukti nyata hasil tes prasiklus kelas IV SDN Geneng 2 menunjukkan bahwa hasil prasiklus siswa dalam materi FPB dan KPK masih rendah dan banyak siswa belum mecapai KKM yang ditentukan yaitu 70. Rata-rata nilai prasiklus sebanyak 42,71 . Dengan $36 \%$ atau 5 siswa yang tuntas mencapai KKM dan $64 \%$ atau 9 siswa yang belum tuntas mencapai KKM dengan jumlah 14 siswa dalam satu kelas. hal ini membuktikan bahwa kemampuan pemecahan masalah matematis siswa masih sangat rendah. Berdasarkan hasil wawancara dengan siswa bahwa guru jarang melatih mneyelesaikan soal cerita sehingga menyebabkan kemampuan pemecahan masalah matematis siswa sangat rendah.

Berdasarkan bukti-bukti tersebut dapat ditarik kesimpulan bahwa kemampuan pemecahan masalah matematis kelas IV SDN Geneng 2 masih rendah dan belum menacapai hasil yang maksimal. Hal ini dapat dilihat dari hasil tes prasiklus, siswa belum bisa memahami soal dengan baik. Sehingga siswa belum mampu menentukan strategi penyelesaian masalah dengan tepat. Maka proses dalam melakukan penyelesaian masalah yang dilakukan oleh siswa juga salah. Begitupun juga dengan proses memeriksa kembali. Lemahnya siswa dalam memahami masalah dikarenakan siswa terbiasa dan selalu terlatih dengan mengerjakan soalsoal essay dengan pertanyaan yang jelas dan mudah dipahami. Sehingga siswa mudah mengerjakannya.

Permasalahan rendahnya kemampuan pemecahan masalah matematis dalam penelitian ini senada dengan hasil penelitian yang dilakukan oleh Kurniadi dan Purwaningrum (2018) dengan hasil penelitian yang dapat disimpulkan bahwa rendahnya kemampuan pemecahan masalah matematis dikarenakan siswa tidak bisa memahami masalah dan tidak bisa melakukan operasi hitung dengan baik. Dengan banyaknya permasalahan tersebut dapat disimpulkan bahwa tidak hanya siswa di SDN Geneng 2 saja tetapi masih banyak siswa- siswa lain yang masih rendah dalam kemampuan pemecahan masalah matematis.

Kenyataan dalam dunia pendidikan pada muatan pembelajaran matematika kemampuan utama yang harus dikembangkan dan dikuasai adalah kemampuan pemecahan masalah matematis. Tujuan penting pembelajaran matematika adalah penanaman kemampuan pemecahan masalah matematis yang merupakan jantungnya matematika (Branca, 1980). Tidak hanya itu kemampuan pemecahan masalah juga sangat penting menjadi bekal siswa untuk memecahkan masalah dalam kehidupan seharihari dan bekal untuk berkompetensi secara global.

Adanya permasalahan lemahnya proses pembelajaran dan minimnya kemampuan pemecahan masalah matematis di kelas IV SDN Geneng 2. Salah satu upaya yang dapat 
dilakukan dalam menciptakan pembelajaran yang berkualitas untuk meningkatkan kemampuan pemecahan masalah matematis adalah menggunakan salah satu pendekatan pembelajaran saintifik. Teori Dyer (dalam Sani, 2015:53) menyatakan bahwa pembelajaran saintifik merupakan suatu proses pembelajaran yang dirancang sedemikian rupa agar peserta didik aktif dengan tahapan-tahapan mengamati, menanya, mencoba/mengumpulkan informasi, menalar, dan melakukan komunikasi.

Salah satu pendekatan pembelajaran saintifik adalah pembelajaran inkuri. Pembelajaran inkuiri adalah salah satu pembelajaran yang menekankan keaktifan siswa dalam pembelajaran. Shoimin (2014: 85) menyatakan bahwa pembelajaran inkuiri merupakan rangkaian pembelajaran yang berorientasi pada keaktifan peserta didik untuk menadpatkan pengalaman belajar dalam menemukan konsep atau pengetahuan materi sesuai permasalahan yang diajukan. salah satu keunggulan pembelajaran inkuiri adalah menekankan pengembangan aspek kognitif secara progresif. Adapun ciri khas dalam pembelajaran inkuiri adalah pembelajaran yang menekankan aktivitas siswa untuk mencari dan menemukan suatu konsep atau pengetahuan sendiri. Adapun langkah-langkah pembelajaran inkuiri adalah (1) orientasi, (2) merumuskan masalah, (3) merumuskan hipotesis, (4) mengumpulkan data, (5) menguji hipotesis, (6) kesimpulan. Dengan pengalaman mencari atau menemukan konsep yang dilakukan oleh siswa sama saja kita melatih siswa untuk memahami suatu masalah. Sedangkan konsep yang ditemukan memudahkan siswa untuk menentukan strategi pemecahan masalah dan menyelesaikan suatu masalah.

Dale (dalam Sani, 2016: 60-61) menyatakan bahwa dalam kerucut pengalaman, daya ingat dari apa yang dibaca dan didengar sebesar 20\%, mengingat apa yang dilihat sebesar $30 \%$, mengingat dari apa yang dilihat dan didengar sebesar 50\%, mengingat dari apa yang dikatakan sebesar $70 \%$, mengingat dari apa yang dilakukan sebesar $90 \%$. Berdasarkan teori tersebut siswa yang hanya membaca dan mendengar dalam pembelajaran hanya memiliki daya ingat $20 \%$ untuk mengingat pengetahuan yang didapat dalam belajar. Sehingga siswa sering mudah lupa ketika sudah mendapatkan pengetahuan dan ilmu yang didapat dan pembelajaran menjadi tidak bermakna.

Pembelajaran yang memberikan pengalaman nyata langsung dilakukan oleh siswa dalam mencari atau menemukan konsep atau pengetahuan dan melakukan presentasi hasil konsep yang ditemukan memiliki daya ingat sebesar $90 \%$. Dengan ini siswa tidak akan mudah lupa dengan apa yang sudah didapatkan dan siswa tidak perlu lagi mengahafal rumus. Hal ini memudahkan siswa untuk menyelesaikan masalah dengan percaya diri. Untuk itu dengan pembelajaran inkuiri mampu meningkatkan kemampuan pemecahan masalah matematis dalam pembelajaran matematika.

Pembelajaran inquiry mampu meningkatkan kemampuan pemecahan masalah matematis. Dalam pembelajaran inquiry membuat siswa lebih aktif bertanya dan melakukan diskusi dalam pembelajaran. Dalam hal ini pembelajaran inkuiri memberikan peluang dalam pembelajaran matematika untuk mengoptimalkan pembelajaran dengan aktifitas siswa dan menjadikan motivasi belajar siswa untuk mencapai hasil belajar yang lebih baik (Nadhifah dan Afriansyah, 2016).

Menunjang pembelajaran inkuiri menjadi pembelajaran yang efektif dan efisien, dibutuhkan media pembelajaran yang sesuai dengan karakteristik pembelajaran inkuiri untuk mencapai tujuan pembelajaran. Dalam hal ini guru berperan sebagai fasilitator untuk menunjang pembelajaran. Piaget (dalam Pitadjeng: 2015: 36) menyatakan bahwa anak SD yang berusia 6/7 - 12 tahun membutuhkan bantuan manipulasi benda-benda konkret yang relevan untuk mendapatkan pengalaman langsung. Adapun salah satu media benda konkret untuk mendapatkan pengalaman langsung sesuai dengan pembelajaran inkuiri adalah media puzzle. Dengan media puzzle memudahkan siswa untuk bermain secara nyata atau dapat dipegang secara langsung dalam menemukan sebuah konsep atau pengetahuan sesuai dengan permasalahan. Terutama permasalahan terkait dengan materi keliling dan luas persegi panjang dan segitiga.

Turmudi (2009: 90) menyatakan bahwa game dan puzzle adalah salah satu sarana membangunkan siswa untuk melek matematika. Dengan digunakannya game dan puzzle dalam pembelajaran matematika menjadikan perubahan yang awal mulanya siswa tidak menyukai pembelajaran matematika berganti menjadi pembelajaran yang disukai oleh siswa. Puzzle adalah permaianan edukatif bongkar pasang dengan cara menyusun kepingankepingan puzzle untuk membentuk sebuah gambar. 


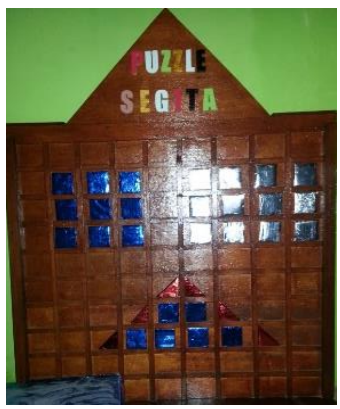

\section{Gambar 1. Media Puzzle Segita}

Media puzzle yang digunakan dalam penelitian ini adalah puzzle segita. Media puzzle segita merupakan salah satu media permainan. Puzzle segita adalah permainan bongkar pasang kepingan puzzle yang terdiri dari kepingan satuan persegi dan segitiga. Permainan puzzle ini digunakan untuk menemukan sebuah konsep keliling, luas persegi panjang, dan segitiga. Media puzzle segita digunakan pada tahap menguji hipotesis dimana siswa berdiskusi menyelesaikan masalah dalam menemukan konsep keliling dan luas persegi, persegi panjang dan segitiga berdasarkan data-data yang ditemukan dalam menyelesaikan pertanyaan. Dan pada tahap kesimpulan dimana guru memberi penguatan materi ketika menyimpulkan hasil diskusi. Sehingga penerapan pembelajaran inkuri berbantuan media puzzle segita dapat menggerakkan siswa aktif dalam pembelajaran matematika dan memberikan pengalaman nyata kepada siswa yang terlibat secara langsung dalam menemukan sebuah konsep atau pengetahuan sendiri sehingga pembelajaran matematika menjadi bermakna.

\section{METODE PENELITIAN}

Jenis penelitian ini adalah Penelitian Tindakan Kelas (PTK) yang dilaksanakan di kelas IV SDN Geneng 2 Mijen, Kabupaten Demak, Jawa Tengah, Indonesia. Penelitian ini dilakukan dari prasiklus hingga siklus II.

Subjek dalam penelitian ini yaitu peneliti sebagai guru dan siswa kelas IV tahun pelajaran 2018/2019 berjumlah 14 siswa, terdiri dari 11 siswa perempuan dan 3 siswa laki-laki. Dengan dipilihnya SD tersebut sebagai tempat pelaksanaan penelitian karena rendahnya kemampuan pemecahan masalah matematis, minimnya media pembelajaran yang dimiliki sekolah tersebut dan masih mengaplikasikan pembelajaran konvensional dalam pembelajaran kurikulum 2013.
Penelitian tindakan kelas ini dilakukan menggunakan model Kemmis dan Mc Taggart dengan skema seperti gambar 2 .

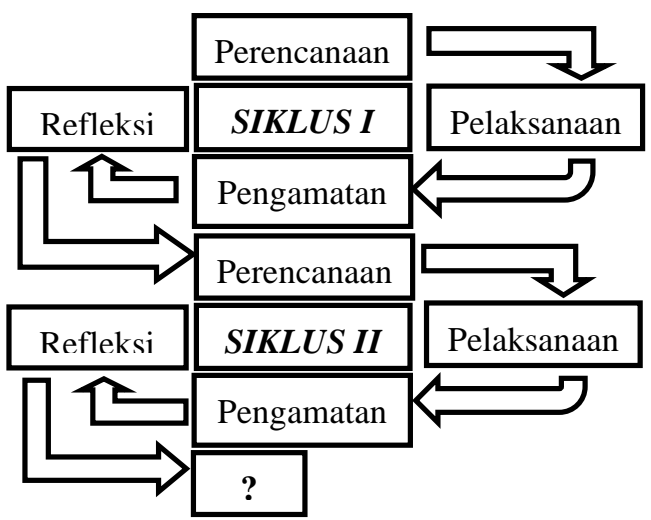

Gambar 2. Model PTK Desain Kemmis dan Mc Taggart

Teknik pengumpulan data dalam penelitian ini adalah teknik tes dan teknik non tes. Teknik tes guna untuk mengukur kemampuan pemecahan masalah matematis. Tes evaluasi penelitian ini berjenis tes uraian sebanyak 5 soal dengan materi keliling dan luas persegi, persegi panjang dan segitiga sesuai indikator kemamapuan pemecahan masalah matematis. Sedangkan teknik non tes yang dipakai adalah wawancara, observasi, dan dokumentasi. Analisis data yang digunakan adalah analisis data kuantitatif digunakan untuk menganalisis angka rata-rata dan persentase sedangkan analisis kualitatif digunakan untuk analisis deskriptif.

\section{HASIL DAN PEMBAHASAN}

Pelaksanaan penelitian tindakan kelas dilaksanakan selama 2 siklus, yakni siklus 1 dan siklus 2. Setiap tindakan persiklus dilaksanakan sebanyak 4 kali pertemuan. Siklus 1 dilaksanakan pada tanggal 25-29 April 2019. Sedangkan tahap siklus 2 dilaksanakan pada tanggal 30 April - 4 Mei 2019. Setiap pertemuan dilaksanakan dengan alokasi waktu 2 x 35 Menit. Penelitian ini dilaksanakan pada tahun ajaran 2018/2019 disesuaikan dengan materi keliling dan luas persgei,persegi panjang, dan segitiga.

Berdasarkan hasil observasi dan wawancara yang dilakukan oleh peniliti menunjukkan bahwa terdapat permasalahan dalam pembelajaran matematika yaitu lemahnya kemampuan pemecahan masalah matematis siswa yang sangat rendah. Hasil kemampuan pemecahan masalah matematis siswa pada tahap prasiklus menunjukkan hasil diperoleh jumlah 
rata-rata 43. Berdasarkan data tersebut persentase ketuntasan secara klasikal siswa yang tuntas mencapai $36 \%$ dengan kualifikasi kurang baik dan persentase siswa yang tidak tuntas mencapai 64\% dengan kualifikasi kurang baik.

Hasil kemampuan pemecahan masalah matematis siswa pada tahap siklus I menunjukkan hasil bahwa diperoleh jumlah ratarata 69 dengan persentase ketuntasan klasikal mencapai $71 \%$ berkualifikasi cukup baik. terdapat 10 siswa yang tuntas mencapai persentase $71 \%$ dengan kualifikasi cukup baik. Dan siswa yang tidak tuntas sebanyak 4 mencapai persentase 29\%. Sedangkan pada siklus II menunjukkan hasil nilai evaluasi dengan jumlah rata-rata sebesar 85 diperoleh persentase ketuntasan klasikal $86 \%$ dengan kualifikasi sangat baik. Pada tahap siklus II terdapat 12 siswa yang tuntas mencapai KKM dengan persentase ketuntasan klasikal $86 \%$. Dan siswa yang tidak tuntas berjumlah 2 mencapai persentase $14 \%$.

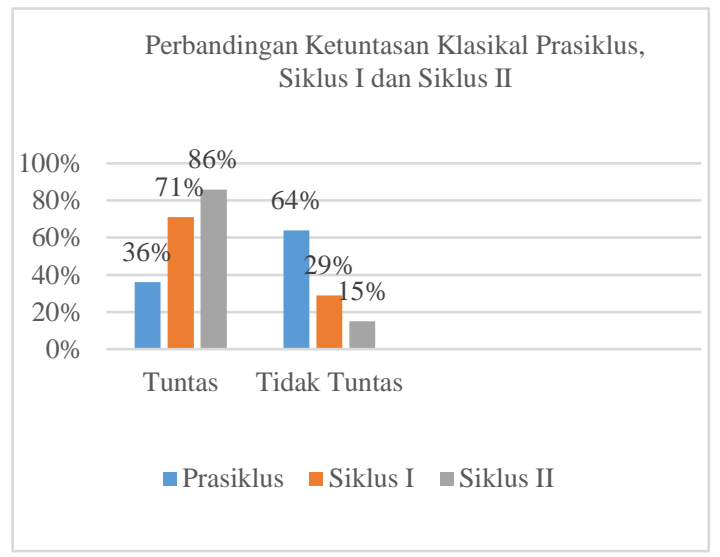

\section{Gambar 3. Diagram Batang Persentase Ketuntasan Kemampuan Pemecahan Masalah Matematis}

Hasil aktivitas belajar pada siklus I memperoleh jumlah rata-rata 80 dengan predikat cukup baik. Berdasarkan hasil observasi aktivitas belajar siswa siklus 1 terdapat 11 siswa yang tuntas mencapai KKM yang ditentukan dan 3 siswa yang tidak tuntas. Hasil perolehan aktivitas belajar siswa pada siklus II memperoleh jumlah rata-rata 88 mencapai persentase $93 \%$ dengan kualifikasi sangat tinggi. Berdasarkan hasil peningkatan observasi aktivitas belajar siswa pada siklus II terdapat siswa mencapai ketuntasan yang ditentukan sebanyak 13 siswa. Dan siswa yang tidak tuntas mencapai ketentuan yang ditentukan sebanyak 1 siswa. Adapun jumlah rata-rata yang ditentukan dalam aktivitas belajar siswa yakni $\geq 70$ dengan predikat baik.

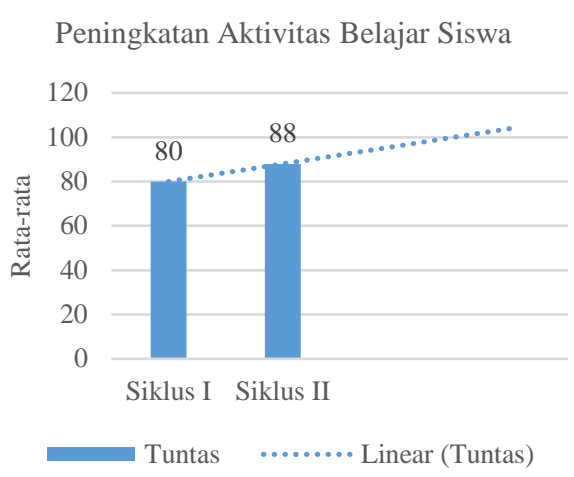

Gambar 4. Diagram Batang Persentase Aktivitas Belajar Siswa

Hasil keterampilan mengajar guru menunjukkan hasil observasi pada siklus I diperoleh total skor 588 mencapai persentase keberhasilan $74 \%$ dengan kualifikasi cukup baik. Dan pada siklus II diperoleh total skor 695 terjadi peningkatan mencapai persentase keberhasilan sebesar $87 \%$ dengan kualifikasi sangat baik. Berdasarkan hasil tersebut adanya peningkatan persentase keberhasilan keterampilan mengajar guru dari siklus I hingga siklus II sebesar $13 \%$.

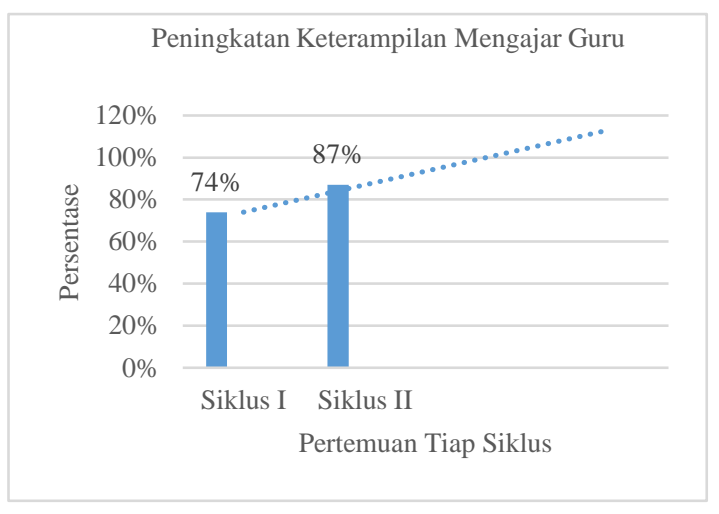

\section{Gambar 5. Diagram Batang Persentase Keterampilan Mengajar Guru}

Meningkatnya kemampuan pemecahan masalah matematis siswa, aktivitas belajar siswa, dan keterampilan mengajar guru adanya penerapan pembelajaran inkuiri berbantuan puzzle segita. Prasetyo, dkk (2015) menyatakan bahwa banyak sekali model pembelajaran yang berkembang untuk mengatasi permasalahan dalam dunia pendidikan salah satunya yaitu model pembelajaran inkuiri. Shoimin (2014: 85) menyatakan bahwa pembelajaran inkuiri 
merupakan kegiatan pembelajaran yang mengaktifkan siswa untuk menciptakan pengalaman belajar dalam menemukan konsep materi yang akan dipelajari. Adapun Purwasih (2015) mengemukakan bahwa salah satu misi pembelajaran matematika adalah menerapkan pemahaman konsep matematika yang dibutuhkan untuk memecahkan masalah yang dihadapi. Pembelajaran inkuiri sangat dibutuhkan dalam meningkatkan kemampuan pemecahan masalah matematis siswa. Ritonga (2017) menyatakan bahwa melalui pembelajaran inkuiri pemahaman akan konsep menjadi modal yang cukup penting dalam melakukan pemecahan masalah karena dalam menentukan strategi pemecahan masalah diperlukan penguasan konsep yang mendasari permasalahan tersebut.

Prabawati (2018) menyatakan bahwa manfaat media belajar adalah dapat membantu anak dalam mendapatkan informasi dan memudahkan proses belajar siswa dengan bermain. Media pembelajaran yang digunakan dalam penelitian ini untuk memudahkan siswa dalam menemukan sebuah konsep yaitu puzzle segita. Arifuddin, dkk (2017) menyatakan bahwa media puzzle sangat menarik siswa untuk mneyusun, merangkai, dan mencocokkan bentuk potongan puzzle pada tempatnya yang sangat cocok diterapkan pada materi bangun datar. Media puzzle segita merupakan permainan bongkar pasang yang terdiri dari kepingan persegi satuan dan segitiga satuan untuk menemukan konsep keliling dan luas persegi, persegi panjang, dan segitiga. Melalui puzzle segita dimana siswa bermain bongkar pasang menyusun sebuah bangun persegi, persegi panjang, dan segitiga dengan kepingan puzzle yang berbentuk persegi dan segitiga. Setelah penyusunan dilakukan siswa akan mudah menemukan konsep bangun datar yang telah disusun. Media puzzle segita digunakan pada tahap mengumpulkan data, dan menguji hipotesis. Hal ini diperkuat dengan pernyataan Muhassanah,dkk (2014) menyatakan bahwa dalam pembelajaran geometri diharuskan dapat memvisualisasi, menggambar serta membandingkan bangun geometri dalam berbagai posisi guna mengembangkan pemahaman siswa.

Pelaksanaan pembelajaran dalam penelitian ini menggunakan model pembelajaran inkuiri. Dalam model pembelajaran inkuiri lebih berpusat pada aktifitas belajar siswa dan guru hanya sebagai fasilitator. Burhanuddin (2017) menyatakan bahwa dalam pembelajaran inkuiri guru di kelas berperan sebagai konsultan, teman yang kritis daln fasilitator sehingga memberikan kemudahan untuk siswa yang berkelompok. Aktifitas belajar siswa yang dilakukan dalam penelitian ini dianataranya siswa merumuskan masalah, siswa merumuskan hipotesis pada lembar kerja siswa, siswa berdiskusi menemukan konsep, siswa melekuakn presentasi dan memebrikan sanggahan. Rahmadani (2017) menyatakan bahwa aktivitas belajar merupakan seluruh aktivitas dalam proses belajar terdiri dari kegiatan fisik hingga kegiatan psikis. Adapun kegiatan fisik merupakan keterampilan dasar diantaranya mengobservasi, mengklasifikasi, memprediksi, mengukur, dan menyimpulkan, dan mengkomunikasikan. Adapun pelaksanaan pembelajaran inkuiri dalam penelitian ini sebagai berikut.

1. Kegiatan orientasi.

Dalam kegiatan orientasi guru menyiapkan psikis dan fisik siswa sebelum pemeblajaran dimulai. Setelah itu guru membuka pemeblajaran dengan mengucap salam, melakukan absensi, dan melakukan apersepsi. Setelah itu guru menyampaikan materi, kompetensi dan tujuan pembelajaran yang harus dicapai. Tak lupa juga guru memberikan motivasi pembelajaran. Sefani (2017) menyatakan bahwa motivasi belajar merupakan faktor intrinsik siswa salah satunya kesiapan belajar. Adanya kesiapan fisik, mental maupun emosional dapat memberikan dorongan motivasi siswa dalam proses pembelajaran yang dapat berakibat hasil belajar meningkat.

2. Merumuskan Masalah

Dalam kegiatan ini guru memberikan beberapa pertanyaan atau masalah dan siswa merumuskan masalah tersebut. Hal ini untuk mengetahui sebarapa besar pengetahuan terhadap materi yang akan di pelajari. Dalam hal ini guru harus memiliki keterampilan bertanya yang baik. Burhanuddin (2017) menyatakan bahwa kemmapuan guru dalam teknik bertanya merupakan syarat utama yang dilakukan dalam dalam pendekatan inkuiri. Sedangkan siswa yang yang dapat merumuskan masalah merupakan siswa yang siap dalam mengikuti kegiatan pembelajaran. Sefani (2017) menyatakan bahwa tercapainya belajar siswa dipengaruhi oleh faktor internal atu kesiapan belajar siswa. kesiapan belajar siswa adalah kondisi seseorang yang siap untuk memberi suatu respon atau jawaban. 
3. Merumuskan Hipotesis

Kegiatan ini siswa berkelompok berdiskusi merumuskan hipotesis pada lembar kerja siswa. Dengan pembelajaran berkelompok dapat meningkatkan aktivitas belajar siswa melalui komunikasi dan interaksi antar siswa atau anggota dengan baik. Hal ini emmudahkan siswa untuk memecahkan masalah dalam lembar kerja siswa. Rostika (2017) menyatakan bahwa siswa belajar dengan diskusi kelompok leih mudah memecahkan suatu persoalan masalah dibandingkan siswa bekerja secara mandiri.

Dan pada tahap ini guru menjadi fasilitator.

4. Mengumpulkan Data

Kegiatan mengumpulkan data dimana siswa mengumpulkan data berdasarkan rumusan hipotesis yang telah diselesaikan untuk menemukan suatu konsep dengan bantuan puzzle segita. Dalam tahap ini siswa beraktifitas menggunakan puzzle segita untuk menemukan sebuah konsep secara berdiskusi. Dan guru bertugas sebagai fasilitator dan membimbing siswa dalam menemukan konsep.

5. Menguji Hipotesis

Kegiatan menguji hipotesis dalam penelitian ini merupakan kegiatan dimana siswa menyelesiakan latihan soal pada lembar kerja siswa dengan konsep yang ditemukan. Dalam tahap ini setiap kelompok bertanggung jawab dalam menyelesaikan masalah dengan benar. Rahayu (2016) menyatakan bahwa siswa yang menyelesiakan tugas dari guru dengan teliti dan tepat waktu merupakan salah satu dari tanggung jawab. Setiap kelompok menyelesaikan masalah sesuai dengan indikator kemampuan pemecahan masalah diantaranya memahami masalah, merencanakan strategi penyelesaian, melakukan perhitungan, dan melihat kembali serta menyimpulkan hasil. Kriteria siswa yang dapat dikatakan mampu memecahkan suatu masalah apabila ia dapat memahami masalah yang terjadi, mampu memlih cara atau strategi yang tepat, serta dapat menerapkan dalam penyelesaian masalah tersebut (Rostika dan Junita, 2017).

Selanjutnya siswa mempresentasikan hasil diskusi di depan kelas dan guru mengatur jalannya diskusi. Pada tahap ini melatih keberanian dan kepercayan diri siswa. Purwasih (2015) menyatakan bahwa siswa yang terlibat dalam aktivitas mengamati dan membuktikan jawaban sementara yang diselesaikan, siswa termotivasi dalam kegiatan diskusi sehingga menimbulkan komunikasi, keberanian, serta kepercayaan diri mengemukakan pendapat dan mempresentasikan hasil diskusi kelompok di depan kelas

6. Kesimpulan

Guru menyimpulkan hasil diskusi siswa dan menyimpulkan materi. Dalam menyimpulkan materi guru memberikan pertnayaan dan memberikan kesempatan siswa untuk bertanya guna menguatkan materi yang disampaikan. Laksana (2017) menyatakan bahwa Interaksi dengan siswa yang terampil akan menimbulkan suasana belajar yang menyenangkan karena pembelajaran, dimana peserta didik akan senantiasa aktif dalam setiap kegiatan pemeblajaran karena adanya interaksi yang terampil dari pendidik.

Menigkatnya kemampuan pemecahan masalah matematis dalam penelitian ini sama halnya dengan penelitian yang dilakukan oleh Sudibjo dan Handayani (2017) menyatakan bahwa melalui pemeblajaran inkuiri mampu meningkatkan kemampuan pemecahan masalah matematis siswa. Peningkatan aktivitas belajar siswa dalam penelitian ini senada dengan penelitian yang dilakukan oleh Yuliani, dkk (2018) menyatakan bahwa dengan media bongkar pasang mampu meningkatkan aktivitas belajar siswa.

\section{SIMPULAN}

Berdasarkan hasil penelitian tidakan kelas yang telah dilaksanakan dapat ditarik kesimpulan bahwa penerapan pembelajaran inkuiri berbantuan puzzle segita mampu meningkatkan, 1) kemampuan pemecahan masalah matematis, 2) aktivitas belajar siswa, dan 3) keterampilan mengajar guru pada siswa kelas IV SDN Geneng 2.

\section{DAFTAR PUSTAKA}

Amir, Zubaidah dan Risnawati. 2016. Psikologi Pembelajaran Matematika.Yogyakarta: Aswaja Pressindo.

Arifuddin, A., Maufur, S., dan Farida. 2018. Pengaruh Penerapan Alat Peraga Puzzle dengan Menggunakan Metode Demonstrasi Terhadap Motivasi Belajar Siswa Pada Pembelajaran Matematika di SD/MI. Jurnal Ilmiah Sekolah Dasar, 2(1): 10-17. 
Branca, N.A. 1980. "Problem Solving as A Goal, Process and Basic Skill”, Problem Solving in School Mathematics. Reston, VA: NCTM.

Burhanuddin. H. 2017. Pengaruh Pembelajaran Inkuiri Terhadap Aktivitas Dan Hasil Belajar Peserta Didik, VI (2): 305-315.

Depdiknas. 2003. Undang-undang Sistem Pendidikan Nasional. Jakarta: Departemen Pendidikan Nasional.

Hendriana, H. dan Soemarmo, U. 2014. Penilaian Pembelajaran Matematika. Bandung: PT Refika Aditama.

Kurniadi, G., dan Purwaningrum, P. 2018. Kesalahan Siswa Pada Kategori Kemampuan Awal Matematis Rendah Dalam Penyelesaian Tes Kemampuan Pemecahan Masalah Matematis. JPPM, 11(2): 55-66.

Laksana, Dek Ngurah Laba. 2017. Analisis Keterampilan Dasar Mengajar GuruGuru Non Sarjana Sekolah Dasar Di Kecamatan Bajawa Kabupaten Ngada. Jurnal Ilmiah Pendidikan, 1 (1): 51-58

Muhassanah, N., Sujadi, I., dan Riyadi. 2014. Analisis Keterampila Geometri Siswa Dalam Memecahkan Maalah Geometri Berdasarkan Tingkat Berpikir Teori Van Hiele. Jurnal Elektronik Pembelajaran Matematika, 2(1): 54-66.

Nadhifah, G., dan Afriansyah, E., A. 2016. Peningkatan Kemampuan Pemecahan Masalah Matematis Siswa Dengan Menerapkan Model Pembelajaran Problem Based Learning dan Inquiry. Jurnal Pendidikan Matematika STKIP Garut, 5(1): 33-44.

Pitadjeng. 2015. Pembelajaran Matematika Yang Menyenangkan. Yogyakarta: Graha Ilmu.

Prabawati, P. E., Kristiana, D., dan Fadlillah, M. 2018. Pengaruh Puzzle Geomewa Terhadap Kemampuan Dan Minat Anak Dalam Mengenal Bentuk Geometri Pada Kelompok Usia 4-5 Tahun Di Ba'aisyiyah Ronowijayan. Artikel Ilmiah Mahasiswa Universitas Muhammadiyah Ponorogo, 2(2): 139-147.

Prasetyo, D., A. dan Widjanarko, Dwi. 2015. Inquiry Learning Model Application To Improve Student Learning Outcomes Of Maintenance Gasoline Fuel System Components Competence. JPTM: Jurnal Pendidikan Teknik Mesin, 15(2): 82-86.
Purwasih, R. 2015. Peningkatan Kemampuan Pemahaman Matematis Dan Self Confidence Siswa MTS Di Kota Cimahi Melalui Model pembelajaran Inkuiri Terbimbing. DIKDAKTIK: Jurnal Ilmiah STKIP Siliwangi Bandung, 9(1): 16-25.

Rahayu, R. 2016. Peningkatan Karakter Tanggung Jawab Siswa SD Melalui Penilaian Produk Pada Pembelajaran Mind Mapping. Jurnal Konseling Gusjigang, 2(1): 97-103.

Rahmadani N., Nurmala, dan Anugraheni, I. 2017. Improving Math Learning Activities Through Problem Based Learning Approach For 4TH Grade Students. Scholaria: Jurnal Pendidikan Dan Kebudayaan, 7(3): 241 -250 .

Ritonga, M. S. 2017. Peningkatan Kemampuan Pemecahan Masalah Dan Komunikasi Matematik Siswa SMP Negeri 28 Medan Melalui Pembelajaran Inkuiri Dengan Strategi React. AXIOM, VI(1): 1-13.

Rostika, D., Junita, H. 2017. Peningkatan Kemampuan Pemecahan Masalah Siswa SD Dalam Pembelajaran Matematika Dengan Model Diskursus Multy Representation (DMR)

Sani, R. A. 2015. Pembelajaran Saintifik untuk Implementasi Kurikulum 2013. Jakarta: Bumi Aksara.

Sefani, Lyna Latifah. 2017. Pengaruh Keterampilan Mengajar Guru Dan Kesiapan Belajar Terhadap Terhadap Hasil Belajar Ekonomi Melalui Motivasi Belajar Sebagai Variabel Intervening Siswa Kelas XI IS SMA Negeri 14 Semarang. EEAJ: Economic Education Analysis Journal, 6(1): 36-46.

Shoimin, A. 2014. 68 Model Pembelajaran Inovatif Dalam Kurikulum 2013. Yogyakarta: AR-RUZZ MEDIA.

Sudibjo, N. dan Handayani. 2017. Penerapan Pendidikan Pembelajaran Inkuiri Terstruktur Untuk Meningkatkan Kompetensi Keterampilan Koneksi Matematis, Memecahkan Masalah, Dan Komunikasi Matematis. Jurnal Teknologi Pendidikan, 19(2): 114-129.

Susanto, A. 2016. Teori Belajar Pembelajaran di Sekolah Dasar. Jakarta: Kencana Prenadamedia Group.

Turmudi. 2009. Landasan Filsafat Dan Teori Pembelajaran Matematika Berparadigma 
Richa Karlina Nofitasari, Ratri Rahayu dan Jayanti Putri Purwaningrum

Anargya: Jurnal Ilmiah Pendidikan Matematika, Vol. 3 No.1, April 2020

Eksploratif Dan Investigatif. Jakarta: PT Leuser Cita Pustaka.

Yuliani, I., Kanzunnudin, M., dan Rahayu, R. 2018. Penerapan Model Creative Problem Solving Berbantuan Media Bongkar Pasang Untuk Peningkatan Berpikir Kreatif Matematika. Anargya: Jurnal Ilmiah Pendidikan Matematika, 1(1): 30-36. 